Accepted Manuscript (AM) of King, R. and Vullnetari, J. (2009) The intersections of gender and generation in Albanian migration, remittances and transnational care. Geografiska Annaler: Series B, Human Geography 91(1): 19-38 [DOI: 10.1111/j.1471-

0374.2008.00189.x][accepted 11 August 2008; published March 2009].

\title{
THE INTERSECTIONS OF GENDER AND GENERATION IN ALBANIAN MIGRATION, REMITTANCES AND TRANSNATIONAL CARE
}

\section{Russell King and Julie Vullnetari}

ABSTRACT. The Albanian case represents the most dramatic instance of postcommunist migration: roughly 1 million Albanians, one quarter of the country's total population, are now living abroad, most of them in Greece and Italy, with the UK becoming increasingly popular since the late 1990s. This paper draws on three research projects based on fieldwork in Italy, Greece, the UK and Albania. These projects have involved in-depth interviews with Albanian migrants in several cities, as well as with migrant-sending households in different parts of Albania. In this paper we draw out those findings which shed light on the intersections of gender and generations in three aspects of the migration process: the emigration itself, the sending and receiving of remittances, and the care of family members (mainly the migrants' elderly parents) who remain in Albania. Theoretically, we draw on the notion of 'gendered geographies of power' and on how spatial change and separation through migration reshapes gender and generational relations. We find that, at all stages of the migration, Albanian migrants are faced with conflicting and confusing models of gender, behavioural and generational norms, as well as unresolved questions about their legal status and the likely economic, social and political development of Albania, which make their future life plans uncertain. Legal barriers often obstruct migrants and their families from enjoying the kind of transnational family lives they would like.

Key words: Albanian migration; gender; generations; family; remittances; transnational care.

[The Version of Record of this manuscript has been published and is available in Geografiska Annaler: Series B, Human Geography; March 2009; DOI:

10.1111/j.1471-0374.2008.00189.x]. 
Accepted Manuscript (AM) of King, R. and Vullnetari, J. (2009) The intersections of gender and generation in Albanian migration, remittances and transnational care. Geografiska Annaler: Series B, Human Geography 91(1): 19-38 [DOI: 10.1111/j.14710374.2008.00189.x][accepted 11 August 2008; published March 2009].

\section{INTRODUCTION}

This paper looks at gender and generations, especially the interaction between them, as exemplified in recent large-scale emigration from Albania. The dual focus on gender and generation reflects two key socio-demographic parameters which increasingly frame geographers' approaches to unpacking the dynamics of international migration, but which are frequently analysed separately from each other. More than ten years ago Skeldon (1997, p.23) stated that 'one of the challenges of future research will be to balance gender and generational relationships within an integrated structured model of migration'. This is what our paper aspires to do.

Although we are concerned with the singular case of Albanian migration, our research is embedded within the wider, but still largely separate, literatures on gender and generations in migration. For some time now, migration has been theorised and analysed as an explicitly gendered process in which the relationality of gender is embodied in almost every aspect of migrant behaviour (see, inter alia, Anthias 2000; Bjerén 1997; Kofman et al. 2000; Pessar and Mahler 2003; Silvey 2006; Willis and Yeoh 2000). This paper seeks to make a direct response to the question: what do contemporary migrations reveal about the changing nature of the patriarchal relations of migration? (King et al. 2006, p.251). Albania is a near-perfect setting in which to try to answer this question, both because it remains a highly patriarchal society (we elaborate on this presently), and because it has experienced intense emigration since the demise of communism in the early 1990 .

The incorporation of the generational dimension into the study of migration has been less systematic, partly due to confusion over the meaning of the word 'generation': is it a life-stage, a principle of kinship, or a cohort? (Kertzer 1983). American and increasingly European literature talks extensively about first-generation (i.e. foreign-born) and second-generation (i.e. native-born) migrants (Thomson and Crul 2007), but our use of generation here is based on a flexible and common-sense meaning of how lifecycle and descent interact with the migration process. What is more important to stress is that, still today, very few attempts have been made to integrate generation and gender in studies of migration and patriarchy. Our evidence, 
Accepted Manuscript (AM) of King, R. and Vullnetari, J. (2009) The intersections of gender and generation in Albanian migration, remittances and transnational care. Geografiska Annaler: Series B, Human Geography 91(1): 19-38 [DOI: 10.1111/j.14710374.2008.00189.x][accepted 11 August 2008; published March 2009].

drawn from multi-sited research in Albania and three destination countries, and involving interviews with 200 individuals affected by migration, is rather comprehensive in its ability to answer Skeldon's plea.

Our analysis addresses three aspects of the Albanian migration process: the initial migration and its evolving aftermath of family reunion and settlement in the host society; the phenomenon of remittance transfer by migrants to family members in Albania; and transnational care between family members abroad and at home. Each of these elements in the migration system is cross-cut by the two axes of gender and generations, forming a sixfold matrix which functions as the organising grid for this paper.

Empirical material comes from three research projects we have been recently involved in, each of which has generated its own separately-themed outputs.

1. Albanian migration to Italy and the dynamics of social exclusion/inclusion. This project, financed by the Leverhulme Trust, 2001-03, collected indepth interviews with migrants $(n=68)$ in two regions of Italy: Lecce in the South, and Bologna and Modena in the North (see King and Mai 2004).

2. Albanian migration to the UK and its developmental impact on Albania. This research was commissioned by Oxfam, 2002-03; remittances were a key feature. Interviews were carried out in the London area $(n=26)$ and with migrant-sending and returnee households $(n=46)$ in northern and central Albania: see King et al. (2003, 2006), also Dalipaj's (2005) thesis.

3. Research on transnational care of the elderly left behind in Albania. Fieldwork involved in-depth interviews in four villages in south-east Albania ( $n=38$ ) and with migrants from these villages in the Greek city of Thessaloniki $(n=23)$. The research was financed by the UK Economic and Social Research Council, 2004-07. Outputs were King and Vullnetari (2006); Vullnetari and King (2008).

The next section of the paper provides background information on post-1990 Albanian emigration. This is followed by a brief combined overview of methods, theory, and application to the Albanian case. The main body of the paper is structured into three parts dealing successively with migration, remittances, and transnational family care. In each of these three sections the 
Accepted Manuscript (AM) of King, R. and Vullnetari, J. (2009) The intersections of gender and generation in Albanian migration, remittances and transnational care. Geografiska Annaler: Series B, Human Geography 91(1): 19-38 [DOI: 10.1111/j.14710374.2008.00189.x][accepted 11 August 2008; published March 2009].

social demographics of gender and generations will be analysed as intersecting dimensions. A conclusion highlights the significance of our findings and points up avenues for further research. Figure 1 is a reference map of Albania.

\section{ALBANIAN MIGRATION}

Much more than other former Eastern bloc countries, Albania has been hugely affected by emigration since the collapse of more than 45 years of communist rule. Recent estimates (Government of Albania 2005) enumerate at least 1 million Albanians currently residing abroad, especially in Greece (600,000), Italy $(250,000)$ and the United Kingdom (50,000). Other European countries and North America also host growing numbers of Albanians as the emigration process undergoes a spreading 'diasporisation' (Mai 2005). With a resident population of just over 3 million at the 2001 census, approximately one in four Albanians now lives abroad.

The post-1990 mass emigration of Albanians was not without historical precedent. During the late $15^{\text {th }}$ century an estimated 200,000 Albanians fled, primarily to Italy, to escape the Ottoman conquest (Tirta 1999). Later, many Albanians migrated within the frontierless Ottoman Empire; their mobility, known as kurbet, reflected the poverty of their mountainous agro-pastoral homeland and the lack of alternative employment options. During the late $19^{\text {th }}$ and early $20^{\text {th }}$ centuries Albanians from the south of the country migrated in significant numbers to the United States. Then, during the long communist interlude, emigration was regarded as an act of treason, punishable by long imprisonment, even death, for those who tried to leave.

Pre-communist migrations were dwarfed by the scale of the 1990s' exodus, which unfolded in the context of dramatic political events, but also against a longer-term background of progressive economic stagnation in rural areas, where most Albanians lived (Sjöberg 1991). Three major migratory episodes were separated by intervening years in which a steadier emigration took place (and continues to do so). The three trigger-points were the chaos which succeeded the demise of communism in 1991-92 (200,000 alone are estimated to have left in those two years), the near-civil-war tension of 1997 when violence erupted after the collapse of a series of pyramid savings scams 
Accepted Manuscript (AM) of King, R. and Vullnetari, J. (2009) The intersections of gender and generation in Albanian migration, remittances and transnational care. Geografiska Annaler: Series B, Human Geography 91(1): 19-38 [DOI: 10.1111/j.14710374.2008.00189.x][accepted 11 August 2008; published March 2009].

(bankrupting most households in Albania), and the Kosovo refugee crisis of 1999 which destabilised northern Albania. Flotillas of boat migrants arriving on the Italian coast were the unforgettable images of 'the exodus' as it was portrayed in the international media, but the biggest migrations took place across the mountainous border with Greece.

The distinctive features of this 1990s' emigration, according to Barjaba (2000), were the following: it was intense (a rate of emigration much higher than other post-communist countries), with a high degree of irregularity (termed 'illegal' by the receiving countries), lots of to-and-fro movement (especially to Greece), and rapidly evolving, with new routes, mechanisms and destinations for migration.

Subsequent revisions of this 'Albanian migration model' have paid more attention to changes after 2000 (Barjaba and King 2005; King 2005). Intensity has faded, although there are few data to monitor recent trends; there has been a shift from irregular to regular migration status, due to regularisations in Italy and Greece in the late 1990s and early 2000s; and shuttle migration has diminished as a result of border patrols and a progressive tendency for Albanians to 'settle down' in host countries. New modalities and motivations for emigration have emerged too, some of which were in evidence soon after the onset of mass migration in the early 1990 . Some migrants leave because of changes in the government - either as political exiles or as lower-level public servants who lose their jobs with each switch in government. There has been substantial student migration, aided by a combination of scholarships and parental support. A re-emergence of bloodfeuds in northern Albania has served as a catalyst for many men to flee the country to escape long-standing vendetta reprisals or obligations. And finally, some young women have emigrated for the purposes of working in the sex industry.

Albanians' experiences as immigrants, especially in the two main host countries, have been shaped by two things - their irregular status, especially before the mid-1990s, and the heavy stigmatisation they received, which portrayed them as a rough, undesirable and criminality-prone people. And yet, despite such a negative stereotype, they have achieved a remarkable and 
Accepted Manuscript (AM) of King, R. and Vullnetari, J. (2009) The intersections of gender and generation in Albanian migration, remittances and transnational care. Geografiska Annaler: Series B, Human Geography 91(1): 19-38 [DOI: 10.1111/j.14710374.2008.00189.x][accepted 11 August 2008; published March 2009].

dynamic socio-economic integration (see Bonifazi and Sabatino 2003; Kelly 2005; King and Mai 2004 for Italy; and Hatziprokopiou 2003; Lazaridis 2004; Pratsinakis 2005 for Greece). This progress has been based largely on individual or family-based initiative. Although some return has taken place (Labrianidis and Hatziprokopiou 2005), the poor state of the Albanian economy discourages return, at least for the time being. Meanwhile, family reunion and the education and socialisation of children abroad makes return less likely for families.

\section{METHODS, THEORY, AND THE ALBANIAN CASE}

The three projects listed in the introduction dealt with three key moments migration itself, remittances, and transnational care. Each project was based on semi-structured interviews lasting upwards of an hour. The interview schedules were not identical across the three projects, but there was a common core of questions which reflected respondents' life histories and migration experiences. In addition to the authors, there were two other interviewers; however, the fact that the first-named author of this paper was the principal investigator or supervisor of all three projects ensured consistency in the research design.

None of the three projects involved explicit questioning on gender and patriarchy (in order not to 'lead' the respondents), but gender and generational relations were analysed as they 'naturally' emerged from interviewees' narratives about their migration histories, remittance behaviour and family care duties. Whilst in the outputs cited against each project the focus is on the particular topic in question (migration and integration, remittances, care), the 'added value' of the present paper is that we draw out the separate threads of gender and generations and weave them together in a combined spatial narrative of social and kin relations.

Because 'lists' of Albanian migrants or migration-affected households do not exist, none of the projects could employ a rigorous sample frame. Opportunistic sampling, based on initial contacts spread over many locations, was the preferred option. Our extensive knowledge of Albanian migration, gathered during ten years of research, enables us to be fairly confident about 
Accepted Manuscript (AM) of King, R. and Vullnetari, J. (2009) The intersections of gender and generation in Albanian migration, remittances and transnational care. Geografiska Annaler: Series B, Human Geography 91(1): 19-38 [DOI: 10.1111/j.14710374.2008.00189.x][accepted 11 August 2008; published March 2009].

the general representativeness of the participants and findings. The multisited research design - across four countries and in different locations within them - further boosts our confidence in this regard (on the value of multisited fieldwork see Marcus 1995). The one caveat is that our interviewees were mostly 'ordinary' working migrants and their kin, not members of the Albanian elite (intellectuals, scientists, political exiles) who have been subject of a separate study (Gedeshi et al. 1999).

Given their nature, our data do not produce frequency tabulations; as with all such essentially qualitative research, our findings derive from indepth engagement with the narrative evidence, from which we distil the metanarratives that emerge as consistent and verifiable themes, triangulated across multiple sites and individuals. We select typical stories and anecdotes that bring the findings 'to life'.

Our theoretical reference-points derive from recent progress in conceptualising migration as a gendered process (see Kofman 2004; Piper 2005; Silvey 2004, 2006) and as one which likewise mediates, and is mediated by, inter-generational relations (King et al. 2006); patriarchy, which is particularly strong in Albania, brings the gender and generation lenses together in one focus. From the many new approaches spawned from a gendered theorisation of migration, we select one as especially appropriate to our analysis: Mahler and Pessar's (2001) gendered geographies of power, to which we add the generation dimension. We are attracted by this framework because of its geographical reference, which we deem essential when analysing migration and the allied transnational practices of remitting and caring, all of which are crucially affected by place, distance and borders. Mahler and Pessar (2001, p.447) commend their approach as 'especially useful for analyzing transnational contexts... and for mapping the historically particularistic circumstances that a given group of people experience... and to analyze them at multiple levels'. The nodal points of their theoretical framework are individuals' social location within interconnected hierarchies (stratified at various geographic scales - national, class, kinship etc.), and the power geometries deriving from contemporary (yet sometimes contradictory) global phenomena such as time-space compression and barriers to 
Accepted Manuscript (AM) of King, R. and Vullnetari, J. (2009) The intersections of gender and generation in Albanian migration, remittances and transnational care. Geografiska Annaler: Series B, Human Geography 91(1): 19-38 [DOI: 10.1111/j.14710374.2008.00189.x][accepted 11 August 2008; published March 2009].

international mobility. Thus, migration can provide new opportunities for women (and men) of various ages to improve their lives, escape oppressive social and family relations, and support those left behind; but it can also expose them to new vulnerabilities as a result of fractured family structures, precarious legal status, abusive working conditions, and intensified patriarchal power (Piper 2005: 1).

How relevant are these theoretical notions to Albania? In a word: very. The rest of the paper will exemplify this, although our dissection of the processes through which patriarchal relations are changing is not unproblematic. One pitfall is the danger of furthering the use of stereotypes through the very analysis of such discursive devices, particularly when they are also articulated by interviewees. This issue is not unknown to human geographers and anthropologists studying migration. Rapport (1995, p.269) writes: 'A world in migration eventuates a heightened emphasis on the stereotyped, the clichéd and proverbial...'. Meanwhile, stereotypes have an ontological appeal even to those who are stereotyped, serving as a vehicle by which 'the migratory individual can anchor himself [and herself] within a conventional and secure social landscape' (1995, p.279).

In this study, the key stereotype, that of the Albanian patriarchal society, is also the baseline of our analysis. Escaping this conundrum is not easy: the best we can do is to draw on the literature on Albanian family structures in order to know what Albanian society looked like before migration took hold. Even this is a challenge because of they way in which both the past and the present are refracted through the distorting prism of the communist era, entwining myth and reality (Schwandner-Sievers and Fischer 2002).

There is, nevertheless, much evidence to document the heavy patriarchalism of 'traditional' Albanian society. Norwegian anthropologist Berit Backer (1983) described Albanian society as 'strictly gender-segregated' and 'one of the most patriarchal in the world'. The traditional Albanian family falls into what Kaser (1992) calls 'Balkan patriarchy', whose key features are a patrilineal kinship system, strong blood ties, ancestor reverence, patrilocality, bride-price, blood-feuds and, above all, family honour. This complex of 
Accepted Manuscript (AM) of King, R. and Vullnetari, J. (2009) The intersections of gender and generation in Albanian migration, remittances and transnational care. Geografiska Annaler: Series B, Human Geography 91(1): 19-38 [DOI: 10.1111/j.14710374.2008.00189.x][accepted 11 August 2008; published March 2009].

hierarchical values is 'embedded in a social structural system defined by both gender and age' where the father has unquestioned authority over his sons (and the rest of the family), the elder brother over the younger, the mother-inlaw over the daughters-in-law, whilst women are subordinated to male supremacy (Halpern et al. 1996, p.247; see also Kera and Papa 2003, Tarifa 2007).

Admirable and insightful as these anthropological writings are, they possess a kind of timelessness which makes it difficult to identify dynamics of change during and since the communist era. Much is made of the medieval customary law, the Kanun, which is too-readily invoked as an explanans for everything that is seen as ultra-traditional or 'deviant' about Albanian social behaviour, both in the past (Shryock 1988; Whitaker 1981) and today (Carver 1999). A thorough study of gender relations under Albanian communism has yet to be made; the simple view is that a kind of 'state feminism' was imposed, with high female participation rates in public administration and in the political arena. This, and other policies and socio-economic changes, brought about significant improvements in family and marital relations for women, such as narrowing the age gap between marriage partners, increasingly marrying for love and not through family mediation, more opportunities for women to file for divorce, and so on (Uçi 2003). Nevertheless, having survived the communist years, many patriarchal traits continue to remain entrenched, especially in rural north Albania, whereas they have been considerably diluted by outside influences in the south. This regional contrast should be kept in mind when interpreting our research findings in the rest of this paper.

\section{MIGRATION, FAMILY, SETTLEMENT}

Since the $19^{\text {th }}$ century, if not earlier, kurbet was framed as an exclusively male phenomenon, summed up by the old Albanian proverb 'a man becomes a man out in the world [i.e. by migrating in search of work], a woman becomes a woman rocking the cradle'. Thus, pre-communist migrations were made up mostly of males; females were left to mourn the separation of their husbands and male relatives. 
Accepted Manuscript (AM) of King, R. and Vullnetari, J. (2009) The intersections of gender and generation in Albanian migration, remittances and transnational care. Geografiska Annaler: Series B, Human Geography 91(1): 19-38 [DOI: 10.1111/j.14710374.2008.00189.x][accepted 11 August 2008; published March 2009].

This male-dominated trend continued after 1990. Published accounts of clandestine migration over the mountains to Greece in the early 1990s speak only of groups of men making this very arduous journey, during which they had to climb steep tracks, often at night and in freezing temperatures, sleeping rough and avoiding the random brutality of the Greek border guards (De Soto et al. 2002; King et al. 1998). Likewise, news reports and pictures of the overcrowded boats docking at the South Italian ports of Bari and Brindisi in 1991 showed an overwhelmingly male refugee population. ${ }^{1}$ As we shall see, these impressions, with women non-existent or invisible, need to be questioned.

\section{Statistics}

As the 1990s evolved, the male:female ratio of Albanian emigration decreased, mainly due to family reunion but also through some independent female migration. According to Italian permit-to-stay records, the female share of the 'stock' of Albanian migrants rose from 14 percent in 1992 to 36 percent in 1999. According to another Italian statistical source, the municipal register, the female Albanian share rose from 24 percent in 1994 to 39 percent in 2000 (Bonifazi and Sabatino 2003). The 2001 Italian census enumerated 41 percent of Albanians as females, exactly the same percentage as the Greek census of 2001.

The picture that emerges is of a traditionally gendered emigration, males departing first, often clandestinely, followed by women and children later, especially after regularised status has been achieved by the males. Bonifazi and Sabatino's (2003) analysis of the Italian permit data shows very clearly that most Albanian men get permits-to-stay for work reasons and a high proportion are single at first migration, whereas women overwhelmingly get permits for family reunion, and are already married.

Statistics from the Albanian side confirm these migration demographics. During the first half of 1990s, 70 percent of the outflow was made up of young males aged 20-30 years (Sokoli and Axhemi 2000). Subsequently the tendency was for emigration to 'normalise' itself demographically, above all by

\footnotetext{
${ }^{1}$ See, for instance, the picture on the front cover of Weiner's (1995) Global Migration Crisis.
} 
Accepted Manuscript (AM) of King, R. and Vullnetari, J. (2009) The intersections of gender and generation in Albanian migration, remittances and transnational care. Geografiska Annaler: Series B, Human Geography 91(1): 19-38 [DOI: 10.1111/j.14710374.2008.00189.x][accepted 11 August 2008; published March 2009].

comprising more females. The 2001 Albanian census recorded the country's first-ever decline in total population. Comparisons with the previous (1989) census using the census residual method $^{2}$ revealed a net loss due to emigration of around 600,000 , of whom 58 percent were males and 42 percent females. This loss was concentrated in the young adult cohorts: 16-34 years for men and 20-30 years for women (INSTAT 2002). Survey data from the Korçë region of southern Albania confirm and elaborate this general picture: migrants are especially likely to be young, rural males destined for Greece and going there, at least initially, without legal status. Lack of work in Albania is the main motive to migrate (Arrehag et al. 2006).

\section{Gendered Processes of Emigration}

So much for statistical reportage. Qualitative research shows how Albanian emigration and settlement abroad have been characterised by strongly gendered power relations. The standard model of male-led migration is evidenced in many of our interviews. Based on these narratives, we make three generalisations.

First, emigration represents the projection abroad of historically entrenched patriarchal structures, some of which re-emerged with new force after their partial suppression during the communist interlude. Indeed, emigration not only maintains gendered and generational relations, which are built into the very process of moving (who leaves, who decides who leaves etc.), it can also exacerbate them. This occurs, we suggest, in two ways. First, emigration, by taking family members out of the fixed (and previously hermetically closed) perimeter of Albania, encouraged the transnational redeployment of patriarchal power to ensure 'acceptable' standards of behaviour and honour are maintained in the 'foreign' setting. Hence many Albanian young wives or daughters living abroad are faced with a double bind: on the one hand they observe at close hand how other young women have freedom to run their own lives; on the other they are prevented from doing so by patriarchal control exercised by husbands, fathers and brothers who are all

\footnotetext{
${ }^{2}$ In this calculation, net emigration equals total population change net of natural change (births minus deaths).
} 
Accepted Manuscript (AM) of King, R. and Vullnetari, J. (2009) The intersections of gender and generation in Albanian migration, remittances and transnational care. Geografiska Annaler: Series B, Human Geography 91(1): 19-38 [DOI: 10.1111/j.14710374.2008.00189.x][accepted 11 August 2008; published March 2009].

the more repressive because of the perceived moral 'danger' of the host society (see King et al. 2003, pp.57-59). Second, in the new unregulated economy and society of Albania, where the old (albeit spartan) guarantees of employment and welfare are lost, a vacuum is created in which some poorly-educated young men are marginalised and reassert their masculine authority by violence against each other and towards young women, some of whom are trafficked for prostitution (Mai 2001).

Second, females are discouraged from engaging in the physically challenging and risky migration journeys that lead over the high mountains to Greece, across the Adriatic in a smuggler's dinghy to Italy, or hidden in a truck across the English Channel to the UK. All three trips have their risks: cold, fatigue and capture by the Greek police; sea-sickness, drowning, and interception by Italian coastguards; suffocation and discovery by the British customs authorities. It is not hard to see how, in a patriarchal society, the nature of migration as an inherently hazardous and physically tough event makes it less acceptable for women (except when accompanied by 'trusted' men, usually close family members) to take these migratory journeys.

Third, the irregular status of Albanian migrants in Europe, dependent on physically demanding informal-sector jobs - for instance in agriculture or construction - is another 'filter' which tends to screen out large-scale participation of women in these labour-market niches. Interviews with Albanian immigrants in Greece and Italy, especially in the early years of migration, recall episodes of hunger, unemployment, sleeping rough and arduous foot travel as work was sought often as casual labour on farms (Hatziprokopiou 2006; King and Mai 2004). Although Albanian young women are engaged in informal-sector jobs in Italy and Greece - for instance as domestic cleaners, carers, baby-sitters etc. - this access to the labour market tended to develop a little later, following male settlement and family migration. Hence their social locations are determined by the gender sequencing of 'pioneer male' migration and by gender power relations with both the migrant and host societies.

The above generalisations are, by and large, valid but, like most generalisations, run the risk of creating and reinforcing stereotypes and 
Accepted Manuscript (AM) of King, R. and Vullnetari, J. (2009) The intersections of gender and generation in Albanian migration, remittances and transnational care. Geografiska Annaler: Series B, Human Geography 91(1): 19-38 [DOI: 10.1111/j.14710374.2008.00189.x][accepted 11 August 2008; published March 2009].

ignoring situations which challenge these standard interpretations. In the selection of narrative extracts which follows we nuance these general statements, providing evidence both to back them up but also to refine them.

Our first - long - extract discusses the patriarchal relations which govern Albanian society, and reflects on these to frame a 'counter-hegemonic' independent female migration, departing on one of the boats that left Durrës (the main Albanian port) in the exodus of March 1991. Looking back on some of the social conditions in Albania that shaped her decision to leave, aged 18, Anila (a pseudonym) said:

... there was this very rigid mentality, there was no freedom of action nor of speech... it did not exist, neither within the family nor within society at large... I mean Albanian society is very patriarchal... moreover if you marry you end up being subjected to a higher level of slavery than the one you were used to before... I was not interested then in marriage, I wanted to feel free and fulfilled, wherever this would be possible... I had just finished high school and had passed the first exam to go and study in the University of Elbasan [in Albania]... but right at that time the borders opened and, as I thought this was the only chance to go, I left... I got on the last boat to leave Durrës harbour on 6 March 1991.

\section{What happened that day?}

It's not really about what happened that day, it's just that, as a woman, I felt that my aspirations would have been wasted in Albania... I felt so oppressed... so closed in... I never had the possibility to experience anything, never entitled to express my desires, my thoughts... I mean the very concept of freedom did not exist for us. We always had to live according to what our teachers or parents said. There was a hierarchy to be respected and you could never, ever be yourself. That is why I thought leaving Albania was the only way, and I went to Italy because it was very close, right in front of Durrës [her home town]... anything in order to escape, to feel free (F, 28, Lecce, November 2001). 
Accepted Manuscript (AM) of King, R. and Vullnetari, J. (2009) The intersections of gender and generation in Albanian migration, remittances and transnational care. Geografiska Annaler: Series B, Human Geography 91(1): 19-38 [DOI: 10.1111/j.14710374.2008.00189.x][accepted 11 August 2008; published March 2009].

Anila's search for freedom and independence from the Albanian 'closed' patriarchal society was by no means unique - it characterised many young people's aspirations in the 1990s, especially those living in urban areas such as Tirana and Durrës that had been more 'open' to outside influences, such as Italian TV (Mai 2002). Another aspect of Albanian society's lack of tolerance of difference and diversity is given in the next example. Gender and generational stereotyping - allocating fixed social roles and norms for males, females, young and old, family solidarity etc. - left little room for alternative models of behaviour, and as a result embodied marked homophobia.

The main reason I decided to leave is the fact that I am gay. My family owns quite a large shop... my economic situation was fine. I did not need to look for a job there, I used to work in my parents' shop. But the mentality there is very conservative. The place I was living in was very small and if you did anything with anybody people would find out and they would just humiliate you, treat you like shit. Your friends would desert you... you would simply be alone and isolated, a terrible thing (M, 20s, London, November 2002).

Amongst many accounts of the difficult and dangerous migration journeys, we select two; both refer to the stepwise movement of Albanians to the UK, often via periods spent working or stopping over in Greece and Italy. The first extract typifies the common pattern of male migration to the UK, leaving the interviewee's wife and children in Albania. The second demonstrates that some females do migrate via these dangerous routes, although, in this case, the action received the condemnation of the husband already abroad.

I left Albania two years ago because there was no work there at all. I left my wife and three kids behind. We had no proper place to live, we lived in a shack here in Bathore [a shanty-town on the edge of Tirana] and so I had to go. I went to Naples with a friend and I worked there to save the money to go to Belgium, where I also had a contact who 
Accepted Manuscript (AM) of King, R. and Vullnetari, J. (2009) The intersections of gender and generation in Albanian migration, remittances and transnational care. Geografiska Annaler: Series B, Human Geography 91(1): 19-38 [DOI: 10.1111/j.1471-

0374.2008.00189.x][accepted 11 August 2008; published March 2009].

was a friend... I tried to cross the Channel nine times in the back of a lorry. They [the port authorities] caught us in Ostend or Calais and sent us back... In the parking lot... in Belgium there were lots of lorries and they [smugglers] waited for the driver to go and eat or for him to sleep before loading us... five here, six there, it was incredible... Once they crammed 20-30 people into the same truck and I thought we were all going to suffocate as there wasn't enough air for all of us... Altogether I spent 350,00o lek on the trip [about $\$ 3,500]$. I made most of the money in Italy, the rest I had saved from an earlier working trip to Greece (M, 36, returned emigrant, Bathore, February 2003).

I went on the trip with my 3-year-old daughter. We got in a speedboat to Italy. Shortly after our arrival in Italy the police apprehended us and took away our passports. We escaped and got a train to France. We were told by the agents that we should stay one night in a hotel and continue our trip next morning; instead, they ran off with our money. My daughter and I had to stay out in the open for three nights without food. My husband, who was waiting for us in England, got very angry with me... he blamed me for putting our lives at risk... but I had to come, I could not stay apart for long... When my daughter got sick in France my brother who was in Italy came to help us. He had a fight with the agents I had paid... then he himself helped us get across in the back of a lorry... My daughter and I were sent to hospital. I had lost 12 kilos during the trip... (F, 20s, London, November 2002).

The process of migration and settlement is also gendered in other, more subtle, ways. One 'hidden' gendering emerged from interviews with 'residual' households in various parts of Albania - generally middle-aged or older parents of migrant children. Often, they talked only of their emigrant sons; it was as if their daughters' migration experiences did not count. Indeed, Albanian patrilineal family structures mean that once a daughter is married, 
Accepted Manuscript (AM) of King, R. and Vullnetari, J. (2009) The intersections of gender and generation in Albanian migration, remittances and transnational care. Geografiska Annaler: Series B, Human Geography 91(1): 19-38 [DOI: 10.1111/j.14710374.2008.00189.x][accepted 11 August 2008; published March 2009].

she 'belongs' to her husband and his parental family. 3 This has enormous implications for remittances and care, as we will see later.

An interesting mixing of the old and the new takes place when Albanian women succeed in migrating independently, but cannot escape the 'long arm' of family obligations. Mirela, 25, had migrated to Bologna several years earlier on a student visa and was a care worker in an old people's home at the time of the interview (July 2003), living independently on her modest monthly salary. Her frustration was her family's expectation that she would 'look after' her brother, who had recently moved to Bologna. After several attempts to set him up - 'he can't do anything for himself, he's just a typical Albanian man' Mirela had given up:

My parents don't understand why I won't support and look after my brother. They think that because I'm his sister, I should do everything for him, no matter what he does. They don't understand how things are over here.

\section{Host-Country Attitudes}

Finally, Albanians' strongly gendered behavioural patterns and norms are sometimes reinforced by host-society attitudes which, seizing on certain generalisations and stereotypes, act to reinforce them. The two stereotypes which have been dominant in both Italian and Greek societies' views of Albanians are the (male) criminal and the (female) prostitute. Both stigmatisations have been largely manufactured by the host-society media, latching on to myths and isolated incidents, manipulated by right-wing and racist political voices (King and Mai 2002; Lazaridis 2004; Mai 2005). Albanian interviewees in the UK generally report a lack of racism and media condemnation compared to their experiences in Greece and Italy, but recent news stories about Albanians' involvement in the sex trade in British cities

\footnotetext{
3 Whilst this remains true as a normative statement and the majority of the population continues to regard marriage as the main ambition and focus of their life, there have been some changes in the traditions and core values of families. Women in families no longer discharge the 'obedient slave' role but have more agency, especially in urban areas (Murzaku and Dervishi 2003; Sokoli 2003, pp.6-24).
} 
Accepted Manuscript (AM) of King, R. and Vullnetari, J. (2009) The intersections of gender and generation in Albanian migration, remittances and transnational care. Geografiska Annaler: Series B, Human Geography 91(1): 19-38 [DOI: 10.1111/j.14710374.2008.00189.x][accepted 11 August 2008; published March 2009].

have begun to change that. Into these stereotypes are built powerful gendered roles: Albanian men as violent towards each other and towards the prostitutes they 'control'; and young Albanian women as trafficked sex victims. This potentially affects all Albanians in Britain, men and women alike:

Sometimes I feel discriminated... I mean, everyone is friendly when they chat to me... until they find out I'm Albanian, when... they usually interrupt the conversation and find an excuse to leave... If you read the newspapers you'd think that Albanians are the only ones behaving badly... They humiliate us... they just do it on purpose, only to discriminate against Albanians. I know there are Albanians who make trouble, but not everyone is like that. The public opinion kills me in the UK (F, 20s, London, October 2002).

Anila, whose powerful narrative on Albanian patriarchy opened this part of the paper, had also experienced the 'Albanian as prostitute' stereotype in her work as translator/interpreter for the Lecce law courts. She recalled an incident in the immigration office of the local police station where a policeman had asked her 'how come all Albanian women here in Italy come to be prostitutes?'. Her answer had been quick and clever: 'You don't understand, they come here to learn from the real experts'.

We end this section on a somewhat more positive note, partly to counter the 'stereotype of the anti-Albanian stereotype' which has been our focus above. Amongst the interviews with Albanians in Italy, several stories were recorded about the extraordinary generosity of local people. Accounts were related of spontaneous gifts of food, clothes, furniture, as well as instances of 'guardian angels' who took in newly-arrived Albanians and plied with them genuine love and hospitality. Interestingly, however, those who were 'adopted' and helped in this way were always young women or young families, never single young men. The gendered stereotype becomes clear: single girls need protection and so can be helped; not so young men who are seen as more 'dangerous'. Children are also a good bridge to inter-communal contact, neighbourliness and integration, as Zinn and Rivera (1995) found in their 
Accepted Manuscript (AM) of King, R. and Vullnetari, J. (2009) The intersections of gender and generation in Albanian migration, remittances and transnational care. Geografiska Annaler: Series B, Human Geography 91(1): 19-38 [DOI: 10.1111/j.14710374.2008.00189.x][accepted 11 August 2008; published March 2009].

study of Albanian women who had settled in southern Italian towns in the early 1990 s.

\section{REMITTANCES: GENDER AND GENERATIONAL PERSPECTIVES}

For a decade and a half, remittances have been the mainstay of the Albanian economy. They are substantially higher than the value of exports, and of both foreign direct investment and foreign economic aid. Research confirms remittances are vital for the support of many rural households, but cannot agree on whether remittances meaningfully differentiate non-poor from poor households (see Arrehag et al. 2005; Castaldo and Reilly 2007; De Soto et al. 2002; de Zwager et al. 2005; Zezza et al. 2005).

So much for the general picture. Now for some specific questions regarding the triangular relationship between remittances, gender and generations. Who sends remittances? Who receives them? Who takes decisions about their utilisation? To what extent do remittances act as a vehicle or catalyst for a change in gender relations, or generational change?

How remittances are gendered is an under-explored aspect of the migration-development relationship (Ramirez et al. 2005). The small amount of literature on gendering remittances falls into the reductionist trap of equating gender with sex, being concerned with whether women are 'better' remitters than men - sending more money, more regularly etc. (see, for example: Blue 2004 on Cuba; McKay 2005 and Semyonov and Gorodzeisky 2005 on the Philippines). Wong (2006) studied matrilineal migration from Ghana to Toronto and the remittance practices of female-headed migrant households. What we try to do is rather more nuanced: investigate the way remittances are interwoven with gendered and generational geographies of power in a society which is, still today, resolutely patriarchal.

Two general findings underscore our analysis: the vital role of migration and remittances in sustaining many households; and the key place of 'family' in structuring all aspects of life, including remittances, in Albania. These themes echo through almost every interview. For example: 
Accepted Manuscript (AM) of King, R. and Vullnetari, J. (2009) The intersections of gender and generation in Albanian migration, remittances and transnational care. Geografiska Annaler: Series B, Human Geography 91(1): 19-38 [DOI: 10.1111/j.1471-

0374.2008.00189.x][accepted 11 August 2008; published March 2009].

Migration is keeping Albania alive. If there was no migration... everything would be finished here (F, 65, south-east Albania, January 2005).

This next interview is an evocative statement about the strength of family identity in Albanian society. The speaker is a middle-aged father of emigrant children, living in the highlands of north-east Albania.

Family is the regulator of people... life does not finish with us... you have to think about the future, about the continuity of your blood line... You are a human being only if you have family. Time spent without a family is lost, wasted. It is only for the family that it is worth sacrificing one's labour, one's youth; it's only worth it if it's for the family... because an emigrant, even if he earns money with great sacrifices, has to look back to his family and its most important needs... which are, first and foremost, the house, living conditions; then marriages, funerals, stuff like that... All relatives are responsible [for these things] and must help each other - uncles, cousins, grandmothers, grandfathers, small children, they are all part of the same picture. Nobody helps you but your family.

However, as we have already stressed, the Albanian family is structured along sharply demarcated gender and generational lines. According to the virilocal custom, a woman joins the household of her husband when she marries, usually moving to his childhood home where his family has lived for generations. Traditional Albanian values require the family to care for the elderly, and the youngest son (together with his wife) is assigned the responsibility for looking after his parents in their later years. But the postcommunist 'revolution' in socio-economic relations has substantially modified the conditions in which these familial obligations can be carried out (Fuga 2004). The collapse of the command economy and society, and its frugal yet generally egalitarian welfare system, has created new vulnerabilities for women and older people (Dervishi 2001; UNDP-Albania 2005). On the one 
Accepted Manuscript (AM) of King, R. and Vullnetari, J. (2009) The intersections of gender and generation in Albanian migration, remittances and transnational care. Geografiska Annaler: Series B, Human Geography 91(1): 19-38 [DOI: 10.1111/j.14710374.2008.00189.x][accepted 11 August 2008; published March 2009].

hand younger people have been more or less forced to emigrate in order to guarantee the survival of their families. On the other hand, this emigration removes them from their families, lessening other kinds of support which derive from simply 'being there'. This dilemma is the subject of the next section of our paper, but we mention it here as it is a necessary backdrop to any discussion on remittances.

Based on interview data triangulated across multiple locations, we make the following generalisations about the gendering and inter-generational flow of remittances:

- Most remittances are sent by men to other male family members, typically from a young male emigrant to his father. An obvious exception would be when the recipient is a widowed female living on her own.

- Generally, young single men supporting parents and siblings in Albania, and married men who emigrated on their own, send the largest amounts; the life trajectories of these migrants are still anchored in Albania, at least for the time being.

- Remittances tend to be high in the early years of migration, when the need to support family members back home and improve their living standards is most urgent. Later, remittances may decrease (even though incomes abroad may rise); the crucial factor is family formation abroad. Those who have reunited, or formed their family abroad are more likely to stay away and therefore have their new family and home-making expenses to consider.

- When both partners of a married couple are wage-earners abroad, the money is pooled under the man's control and, according to traditional family gender roles, may only be remitted to his parents, leaving her parents starved of remittances (unless they have sons who have emigrated). Daughters-only families are severely disadvantaged by these gendered remittance practices.

The most typical remittance scenario runs as follows. The receivers are an older couple, aged $50+$, with one or more sons abroad. The father may well have emigrated himself, as a younger man, on a temporary or shuttle basis to 
Accepted Manuscript (AM) of King, R. and Vullnetari, J. (2009) The intersections of gender and generation in Albanian migration, remittances and transnational care. Geografiska Annaler: Series B, Human Geography 91(1): 19-38 [DOI: 10.1111/j.14710374.2008.00189.x][accepted 11 August 2008; published March 2009].

Greece in the early 1990s. Older couples may have pensions from their work during the communist period - either state pensions (generally $\$ 60-70$ per month) for working for the state, or cooperative pensions which are much lower (\$20-30 monthly). A residual, older household might therefore have a combined pension of $\$ 60-100$ : close to, or below, the official poverty line. 4 Leaving aside remittances, most need to supplement pension income with farming, but this too yields little, except for subsistence, due to lack of marketing and other infrastructures. Remittances are sent, received and administered mainly by men; consultation with women is only token, although this is changing, especially in southern Albania. As the volume of remittances grows and as emigrant sons gain maturity and family responsibility, decisions are increasingly taken by them. Although remittance flows reflect long-established family bonds and gendered and generational loyalties and obligations, they can also be the source of intra-family tensions, as we shall see presently.

\section{Sons and Daughters}

Petrit (61) and his wife (58) live in a village in south-east Albania; both their son and daughter have emigrated and live with their families in the UK and USA respectively. In Petrit's account, note how the remittances come only from the son, not from the daughter; and how the financial help hardly compensates the sense of loneliness felt by the couple.

Our son has been able to put bread on our table with the money he has sent... And what is left over, he likes to have a base here as well... for when he visits... so we built a new house... We don't have a pension yet... we live on the remittances our son sends us, whatever little is left over after he has taken care of his problems... And ourselves we try to work the land... That's how we make ends meet...

We have enough to eat and drink... but when the evening comes and

\footnotetext{
4 The extreme poverty line in Albania as measured by the World Bank is 3,047 lek (\$30) and the absolute poverty line is 4,891 lek $(\$ 49)$ per person per month (World Bank 2006). According to INSTAT (2005), average pensions are $\$ 28$ in rural areas and $\$ 85$ in urban areas.
} 
Accepted Manuscript (AM) of King, R. and Vullnetari, J. (2009) The intersections of gender and generation in Albanian migration, remittances and transnational care. Geografiska Annaler: Series B, Human Geography 91(1): 19-38 [DOI: 10.1111/j.1471-

0374.2008.00189.x][accepted 11 August 2008; published March 2009].

we get together at home, only we know how we get through the night. We think of our children with tears in our eyes, we miss them so much [crying]...

Those who have mainly or only daughters see life as having dealt them a tough hand. Time and again in interviews, it was stressed that remittances could not be expected from daughters abroad, as 'they are with their husbands now'; 'they belong to someone else' etc. Rexhep (73) and Feruze (65) have five daughters and no sons. All the daughters are married and live away from their parents' village - in Korçë (nearby regional city), Durrës, Greece and Australia. Here are some extracts from the interview (March 2005).

Feruze: We worked a lifetime and we couldn't make a thing in the house [i.e. any improvements]. Now we have these pitiful pensions. Even my state pension is only 7000 lek [\$70; her husband receives a cooperative pension of $\$ 30] .$. We have daughters... they send you money only if the husband agrees...

Rexhep: When they marry, they separate from their parents, from their father. They create a family of their own just like you did [nodding to his wife]. And she has duties towards her family, her children. She will bring you a packet of cigarettes once in a blue moon.

There are, however, variations on this gendered remittance model. Here are two cases from field interviews in south-east Albania. Selami (58) and Pranvera (54) are farmers with a son, married and living locally (he works for the local administration), and two daughters, both of whom have higher education and who won the 'green card' lottery to go to the US. Both daughters are married there, one works as a nurse, the other in an architect's office. Both daughters send remittances to their parents, which they have used to improve the village house and to finance important family celebrations weddings, births, etc. Our interpretation of this rather exceptional situation is that, with their experience of higher education before they left, and of living in 
Accepted Manuscript (AM) of King, R. and Vullnetari, J. (2009) The intersections of gender and generation in Albanian migration, remittances and transnational care. Geografiska Annaler: Series B, Human Geography 91(1): 19-38 [DOI: 10.1111/j.14710374.2008.00189.x][accepted 11 August 2008; published March 2009].

a more open, egalitarian and prosperous society (cf. Orgocka 2005), the daughters were able to negotiate with their (Albanian) husbands the right to remit to their parents.

The second example is rather different. Tefta (57) and her husband (64) have a son and a daughter, both married and living in Greece and with their own children. Unusually, Tefta, who is speaking, is the dominant figure in this family, which also includes her husband's 80-year-old mother, referred to in the interview as 'grandma'.

They help us a lot: our daughter... and our son. Otherwise what would we do on grandma's 6000 lek [\$60] pension and his [husband's] 2000 lek [\$20] pension? You can’t make ends meet on that... They send the money to us in this way: our daughter [who lives near Athens] sends the money to our son [who lives in Thessaloniki] through the bank, and he then sends the money here to us. He sends it with friends from the village - both money and other things he buys for us.

What is interesting about this case is that, although the daughter is 'allowed' by her (Greek) husband to send remittances, she does so via her brother who therefore 'controls' the remittance transfer with the help of his (male) friends (the journey between the villages in south-east Albania and Thessaloniki is only three hours by car). The daughter, being married to a Greek (who therefore has no remittance obligations of his own), is 'outside' the Albanian patrilineal family system. Her husband is a farmer with (by Greek standards) a big farm, whereas her brother is still struggling financially.

\section{'I am God'}

More 'traditional' patterns of remittance behaviour are observed in the Albanian migration to the UK, which mainly originates from northern Albania, where gender roles are slower to change. In family interviews in northern Albania the phrase 'Unë jam Zot i shtëpisë' - I am God (or Lord or Master) of the house - was a frequent refrain, expressing the endurance of patriarchal 
Accepted Manuscript (AM) of King, R. and Vullnetari, J. (2009) The intersections of gender and generation in Albanian migration, remittances and transnational care. Geografiska Annaler: Series B, Human Geography 91(1): 19-38 [DOI: 10.1111/j.14710374.2008.00189.x][accepted 11 August 2008; published March 2009].

authority, which, as the following example shows, passes from father to son, but with the latter obligated to the former as far as remittances are concerned.

In Albania 'I am God'. There, in England, he is God in his own house... My son makes his own plans, because now he is financially independent from me... [But] if I were to tell him that I need money, he would ask me to go and get it from Western Union no later than tomorrow. I am being sincere with you. If I need money he will send it with the Western Union within an hour (M, 50s, northern Albania, February 2003).

Other interviews reveal a switch to a more negotiated decision-making in favour of the son sending the money:

I have supported my family in Albania... I have sent to Albania a total of $£ 50$,ooo from four years of work in the UK. My family has purchased land for construction, and replaced the furniture in the house... I think of my family and am ready to help them any time they are in need... But I am very careful with the money. I want to know what they intend to do with it, what the money is actually needed for. I tell them how to use the money (M, 20s, London area, October 2002).

This quote also illustrates the large scale of remittances possible from a highwage economy like the London region, certainly much higher than the per capita sums from Greece where - especially for Albanians - wages are low and often (for a family) barely enough to live on. But much depends on family formation - whether there are two incomes or only one, how many children etc. It is also clear that once the emigrant son becomes responsible for his own family (wife, children etc.), the expectation to send remittances to his parents and siblings is much reduced. 
Accepted Manuscript (AM) of King, R. and Vullnetari, J. (2009) The intersections of gender and generation in Albanian migration, remittances and transnational care. Geografiska Annaler: Series B, Human Geography 91(1): 19-38 [DOI: 10.1111/j.1471-

0374.2008.00189.x][accepted 11 August 2008; published March 2009].

We only have a pension. OK, you will say your children are migrants. Yes, but my children have their own children now, and the Greeks don't pay [well]. They can barely take care of their own problems. So, should they help us or look after the needs of their children? (F, 64, south Albania, July 2004).

\section{Conflicts over Remittances}

All the above is not to say that intra-family tensions over remittances do not occur. In her interviews with young Albanian male migrants in London, Dalipaj (2005) came across a small number who had broken regular contacts and obligations with their families in Albania; likewise when she interviewed households in Albania, she found a few who had effectively 'given up' on their errant emigrant sons:

They have not sent much... just for food. I had to ask them to send money for food... They are out of control... In the end my husband gave up and told them to look after only themselves, because we will manage to live off a piece of bread [meaning we will not starve to death] (migrant's mother, northern Albania, February 2003).

But sometimes a softer conflict develops the other way round, in which the migrant generation presses more remittances as gifts on the parents than they really need or want; a kind of 'game' develops in which the parents refuse to spend the remittances on themselves but invest them in a new house or extension to the family home, for when the emigrant children will return. The irony is that they most probably will not return, except for visits, in which case the new houses and flats will only be used as holiday bases. An example:

He sent home $£ 20,000$ little by little, the result of three years work [in England]. I used the money on the house. I did not ask him for anything. I left it to him to send as much as he wanted. He has never questioned me on the use of his money. I decided what to do with it... Now he just sent £100o to spend on New Year's food shopping. I told 
Accepted Manuscript (AM) of King, R. and Vullnetari, J. (2009) The intersections of gender and generation in Albanian migration, remittances and transnational care. Geografiska Annaler: Series B, Human Geography 91(1): 19-38 [DOI: 10.1111/j.1471-

0374.2008.00189.x][accepted 11 August 2008; published March 2009].

him I couldn’t spend £1000 only for New Year’s night... If he comes tomorrow and asks me what I did with his money, I will show him a three-storey house I built for the family... I did not use his money to pay even for a beer for myself... All is there, bricks and cement... (M, 50s, central Albania, January 2003).

Disagreements between spouses on how remittances received should be spent were very rare - perhaps because the interviews were often done in a family or couple setting where the female voice might be 'silenced'. It was impractical to get married women on their own to pursue this question more deeply. Typical answers would be either that the male head of the household takes decisions on behalf of his wife and other family members, always with their interest at heart; or that, when you live in such poverty, there is not much discussion to be had: 'Do you mean we do not need to eat? We don't need to be warm? We don't need windows or doors?'.

Conflicts over the use of remittances and savings are more likely to arise in the emigration setting, between younger couples who are less imbued with old norms and who are exposed to societies with more egalitarian gender roles. Some wives lamented the draining away of so much hard-earned income on remittances to (just) the husband's family, where the money might not be spent wisely. Where wives were 'allowed' to send some remittances to their parents, they would be euphemistically labelled 'presents'. We also uncovered anecdotal evidence of wives secretly sending remittances to their mothers and other female family members without the knowledge of their husbands - a hidden remittance chain also noted amongst Kosovan Albanian women in Switzerland by Dahinden (2008).

TRANSNATIONAL CARE: GENDER AND GENERATIONAL PERSPECTIVES Like remittances, intra-generational care within Albanian households is strongly structured by the institution of family and is thus sharply gendered. Custom requires (young) women to perform the practical care duties for children, those in ill-health, older parents and in-laws, whereas men's responsibility is to secure economic resources. The continuation of these 
Accepted Manuscript (AM) of King, R. and Vullnetari, J. (2009) The intersections of gender and generation in Albanian migration, remittances and transnational care. Geografiska Annaler: Series B, Human Geography 91(1): 19-38 [DOI: 10.1111/j.14710374.2008.00189.x][accepted 11 August 2008; published March 2009].

patterns during communism was a result of restricted mobility, lack of financial resources and an omnipresent ethno-nationalist ideology which made family the only haven for the individual (Lubonja 2001). In the aftermath of the regime's demise, migration has impacted strongly to perpetuate the situation in some cases, but also to bring a certain degree of flexibility and re-shaping of relations in other instances (Murzaku and Dervishi 2003). We found elements of both these positions when we examined the impact of migration on care within the Albanian family. We look first at older parents 'left behind'.

\section{Left like Logs?}

Older people have been one of the groups most economically hard-hit by the dual impact of mass emigration and the post-communist transformation. With minimal pensions, many live in poverty. In the context of non-existent (in rural areas) and very poor (in urban areas) social services, availability of care during times of ill-health or frailty is very limited. The situation is especially dire in rural highland areas; as these become depopulated, networks of kin, which provide the main help during such times, are greatly weakened. Older people frequently lament that they have been 'left like logs', lying around with nothing to do. Family cohesion and 'normality' are disrupted by the scale and selectivity of Albanian migration; in particular, older people are denied their grandparenting role, for them the very raison d'être of life in older age (King and Vullnetari 2006).

However, we found that migrant children generally do perform longdistance care for their elderly parents in Albania, with varying degrees of success. The literature on transnational elderly care is limited to the cases of Italian and Dutch migrants in Australia (Baldassar 2007; Baldassar and Baldock 2000; Baldock 2000). Although the Albanian context is very different, similar long-distance care practices take place: financial (remittances, presents), personal or 'hands on' (during visits), and emotional and moral (through telephones, video-tapes, friends' visits etc.). Our older interviewees acknowledged that such transnational care does take place. But they attach considerable importance to physical proximity, the lack of which heightens 
Accepted Manuscript (AM) of King, R. and Vullnetari, J. (2009) The intersections of gender and generation in Albanian migration, remittances and transnational care. Geografiska Annaler: Series B, Human Geography 91(1): 19-38 [DOI: 10.1111/j.14710374.2008.00189.x][accepted 11 August 2008; published March 2009].

their sense of loneliness and abandonment, not only as care-receivers, but more so as care-givers.

\section{Gendered Care at Home}

As older respondents recounted their fate and lamented the absence of their children and grandchildren, marked gender differences were noted. Often, older men complained that they had to do agricultural work without any help from their sons, or that they were no longer 'served' by their daughters-in-law or grandchildren, as tradition prescribes. Women laid more emphasis on the burden they held within the domestic sphere, particularly as they continue to bear the heaviest share of care responsibilities for their elderly in-laws. The generation of the 'younger old' in their $50 \mathrm{O}$ and 60s, whose migrant children in their 20 s and 30 s are abroad, often live with the 'older old' in their 7os and 80 - parents and in-laws, for whom they have physical and emotional care responsibilities. The older old are usually women, as the large age-gap between partners for this generation usually means that the husband dies first. These care responsibilities sometimes cause dilemmas for those caught in the middle, as they may want to join their children in Greece or Italy, often to help with child-care, but are not able to do so. Ksanthi (66) lives with her husband in the village. She wanted to spend time with her sons and their families in Greece and Italy, but her mother-in-law had Alzheimer's. Ksanthi's husband is also recovering from a serious operation. Thus, all the care tasks and responsibilities for her husband and mother-in-law, as well as work in the apple orchard and looking after the family cow, rested on Ksanthi's shoulders. In the interview, she struggled for words to describe what she has been through.

Besides their mothers-in-law, women in their 50s and 60s may take responsibility for the care of their younger grandchildren, in an effort to help their migrant children to increase their family income. Festim (53) migrates to Veria, Greece to work in agriculture and lives there most of the year. His wife, Barije (50) lives in their village home in south-east Albania. Whilst Festim provides the income for the family, she looks after the house, and cares for his 80-year-old mother. Although their eldest son and his wife, who live in Greece, 
Accepted Manuscript (AM) of King, R. and Vullnetari, J. (2009) The intersections of gender and generation in Albanian migration, remittances and transnational care. Geografiska Annaler: Series B, Human Geography 91(1): 19-38 [DOI: 10.1111/j.14710374.2008.00189.x][accepted 11 August 2008; published March 2009].

form a separate household, Barije looks after their young daughters aged five and two. The youngest son, who is 16 , is looking for ways to emigrate. The interview is with Festim, on one of his visits back to the village.

My wife is here, I have emigrated alone. Whereas our children are there [in Greece]... They come to visit. I have been going to Greece back and forth, because otherwise I would have to take my family with me. My old woman [mother] is 80 years old. So I leave my wife here [to look after her]. My wife looks after things here, agriculture, the children... we miss one another, then I come and visit and go back again. This is emigration... it's better to emigrate with your family, compared to back and forth. But, I have my mother, I can't leave her... Our [eldest] son has two daughters... we have been looking after them here since they were born; he will come and take them away now, because they will go to school in Greece... It's a help for him so that they can earn more money... so that they both are able to work, husband and wife...

In other cases, child-care provision may take a transnational character, as the 'younger old' may divide time between their village in Albania and their migrant children's homes abroad. In addition, this elderly migration is considered a mechanism to reduce the sense of loneliness, maintain and nurture inter-generational links, and, most importantly, practice grandparenting.

\section{Transnational Grandparents?}

Most of the literature on transnational care has focussed on 'transnational mothers' - female migrants whose children remain in their home country (Hondagneu-Sotelo and Avila 1997; Zontini 2001; 2004). Esrivá (2005: 13) suggests that it is now time to speak of other figures: 'transnational grandmothers' who move back and forth between their countries of origin and the country where their children live; and 'transnational daughters' (but in the Albanian context 'transnational daughters-in-law' is more fitting) who care for 
Accepted Manuscript (AM) of King, R. and Vullnetari, J. (2009) The intersections of gender and generation in Albanian migration, remittances and transnational care. Geografiska Annaler: Series B, Human Geography 91(1): 19-38 [DOI: 10.1111/j.14710374.2008.00189.x][accepted 11 August 2008; published March 2009].

fragile elderly in both the origin and destination country. Whilst these are very relevant in the Albanian context, so too are 'transnational sons' and 'transnational grandfathers'. Also vital are the migrants' legal status and the ability of their parents to access travel documents, as the following two cases show.

Niko and Kristina, both in their 7os, lead a transnational life, spending the summers in their village and the winters with their son and his family in Thessaloniki. Homogeneis papers 5 have enabled this family to move across the Albanian-Greek border relatively easily. Their migrant son and his wife are in their 50s, and they in turn have a son, daughter and son-in-law all in their 20s. Men work in construction, while women do day-care jobs and cleaning for elderly Greeks. Whilst there, Kristina does household chores, whereas Niko looks after the great-grandchildren, taking them to the crèche or to the park. In contrast, for Sabri (72) and Nurije (62), whose son and family live near Athens, the Greek immigration policy towards Albanians puts serious obstacles in the way of family cohesion. The children and grandchildren cannot visit often - it was three years since they last saw them - because of problems with their legal status. As parents and grandparents, Sabri and Nurije would like to visit their children, spend time with them, and also help with caring for their grandchildren. However, the visa procedure is costly, long and highly bureaucratic, leaving the family frustrated and separated by the border. Nurije expresses their frustration:

We would like to go and visit them for a month, two or three, depending on the need... Just by using the passport... it should be accessible. Do we have $€_{300}$ or $€ 400$ for the visa? Or can we go to Tirana or Korçë for months and months chasing after it? You can never get a visa... We don't want to leave our country [for good], because it's not easy to leave your country at this age. But we would like to go and help our children... he [son] wants us to go there and be

5 Three-year entry and stay permits for Greece, given to ethnic-Greek Albanians (cf. de Rapper 2004). 
Accepted Manuscript (AM) of King, R. and Vullnetari, J. (2009) The intersections of gender and generation in Albanian migration, remittances and transnational care. Geografiska Annaler: Series B, Human Geography 91(1): 19-38 [DOI: 10.1111/j.1471-

0374.2008.00189.x][accepted 11 August 2008; published March 2009].

with him. He feels sorry for us because his dad is now 72 years old. I am also getting older.

\section{Daughters-in-Law and Mothers-in-Law}

However, the capacity to render and receive care, depending on the financial resources available and the freedom to travel across international borders, is equally important as the desire to care. We cannot assume that 'happy families' are the norm. For instance, mothers-in-law and daughters-in-law often have very different images of how gendered relations within the household should be structured. The following quote reveals some of these dynamics and how migration has brought emancipation for some women:

Arguments and fighting were present in Albania before as well. A mother-in-law and a daughter-in-law have rarely got on well with one another... They respected one another for the sake of their reputation... and neither of them would raise their voice. But, in general they hated one another... Now [here in Thessaloniki] these are different times, we are used to living like this. It's better that the parents live in another house. Because, for instance, if I argue with my husband, she will tell me off. We would argue in Albania too, but there women had to obey and never speak back. But, when I argue with my husband, my mother-in-law will say: it's ok, he is a man, he can do whatever he likes. How would you feel if she says that? Yes, he is a man, but he has obligations towards his family (F, 40s, Thessaloniki, June 2006).

Thus, 'migrating grannies' (King and Vullnetari 2006) are not always the solution to difficult child-care situations in migration. When either the desire or the capacity to give or receive care are lacking, migrants seek other alternatives. We already saw that some children are left behind to be looked after by grandparents in Albania. Another alternative is that of employing a child-minder, who often is an Albanian middle-aged woman, living in the country of destination. Sofika (27) lives with her husband in Thessaloniki. 
Accepted Manuscript (AM) of King, R. and Vullnetari, J. (2009) The intersections of gender and generation in Albanian migration, remittances and transnational care. Geografiska Annaler: Series B, Human Geography 91(1): 19-38 [DOI: 10.1111/j.14710374.2008.00189.x][accepted 11 August 2008; published March 2009].

Looking after their two young children and their home single-handed prevented her from continuing in paid work, until she found a solution:

When my son was three years old, I wanted to work... I found a job in a small garment factory. But, who was going to look after my son? My mother-in-law [Tefta, whom we met earlier] couldn't look after him, because she had her own mother-in-law to look after, and her husband; so they couldn't all come and live here... So then I had to find a woman here who would care for my son... I first paid her $€_{3}$ a day, and then $€ 4 \ldots$ She was also Albanian, older than me, in her 40 os... She was looking after her own son and daughter, so couldn't work herself.

Our interviews contained many similar stories and examples, revealing an interesting mix of both perpetuated and modified gender-dynamics and new migratory initiatives in relation to care.

First, Albanian migrant women are still expected to shoulder most of the responsibilities for looking after their home and children. However, in emergencies, migrant men help out with tasks such as taking children to school, cooking a meal, doing the shopping etc. It is not surprising that change has not been very significant, especially in Greece, since Greek society is itself patriarchal.

Second, when other carers take over migrant women's work, they are almost always migrant women, sometimes relatives such as mothers or inlaws, at other times acquaintances met in the host country, as in the quote immediately above. Thus, although this care substitution has allowed some young migrant women to participate in waged labour, it has perpetuated the gendered role of other women. However, some change was observed when older men undertook limited care tasks whilst abroad.

Third, in the absence of the youngest son and his wife to look after his parents, care and responsibility for them may be taken over by other sons. Certain concessions may have to be made, such as giving up the right to the parental home in exchange for release from caring duties. The move with 
Accepted Manuscript (AM) of King, R. and Vullnetari, J. (2009) The intersections of gender and generation in Albanian migration, remittances and transnational care. Geografiska Annaler: Series B, Human Geography 91(1): 19-38 [DOI: 10.1111/j.14710374.2008.00189.x][accepted 11 August 2008; published March 2009].

another son may be only temporary, until the youngest son and his wife return from emigration.

Fourth, relationships between parents and a daughter and son-in-law continue to display traditional patterns, in that living with one's son-in-law is still considered less appropriate than with one's son. This poses considerable challenges for parents who only have daughters. However, when both migrant partners work, their joint home is increasingly considered as the enterprise of both. The younger migrant generation has largely embraced this mentality, whereas the older generation accepts the situation out of need rather than choice.

\section{CONCLUSION}

This paper's novel focus has been its integrated analysis of gender and generation across three aspects of the Albanian migration process. On the whole it confirms the migration itself as shaped by gender dynamics, and it highlights (with some exceptions) the gender dimension of two sets of transnational responsibilities - 'female' care and 'male' remittances. Our data have produced a strong and nuanced exemplification of Pessar and Mahler's (2001) theoretical framework of gendered and patriarchal geographies of power. Moreover, we find that these relationships are recursive: on the one hand gender and patriarchy organise Albanian migration; on the other hand, international migration also has the potential to reconfigure gender relations and power inequalities.

To sum up, emigration has brought some changes in gender norms and behaviours, whilst perpetuating and even exacerbating others. Albanian migration conforms to the 'traditional' model of male-led labour migration followed by family reunion, but we acknowledge that this conclusion is skewed somewhat by our concentration on rural source-areas and on relatively lowskilled migrant employment in destinations such as London, Lecce and Thessaloniki. Our findings would certainly have been enriched if more respondents with higher educational backgrounds and/or originating from urban areas had been included; the case of Anila quoted towards the beginning of the paper gives some idea of such different perspectives. 
Accepted Manuscript (AM) of King, R. and Vullnetari, J. (2009) The intersections of gender and generation in Albanian migration, remittances and transnational care. Geografiska Annaler: Series B, Human Geography 91(1): 19-38 [DOI: 10.1111/j.14710374.2008.00189.x][accepted 11 August 2008; published March 2009].

Regarding remittances, the conclusion is clear: men are in general control (see also Arrehag et al. 2005). This applies both to the sending and receiving of remittances, which are transmitted mainly by emigrant sons to fathers who manage the spending and investment of remittances on behalf of the wider family. A major 'gender injustice' occurs due to patrilineal and virilocal customs whereby females are 'lost' to their parents upon marriage, which means that the income that they generate through work abroad passes into the remittance channel to their husband's parents, not their own. Changes to this pattern were noted in individual cases, however. Shifts in control over remittances were more likely to be between generations, in favour of remittance-sending sons, rather than cross-gender. ${ }^{6}$

Transnational care arrangements were likewise found to be affected by intersections between gender and generations, as well as by specific Albanian traditions such as the duty of the youngest son (and his wife) to care for his parents in their old age. 'Ownership' of married daughters by the husbands' families had further implications for the role of grandparents' migration for care. In many respects the secondary migration of older people, following their children abroad, is quite 'new' in migration studies. But, again, such moves are directed by traditional norms of gender and patriarchy - to sons' migrant households, not daughters'. And they are framed both by the desire to be with sons and grandchildren, and by the economic rationale of increasing waged-labour income by allowing daughters-in-law to take jobs. Regrettably, such transnational economic and care strategies are often frustrated by visa regimes and difficulties of maintaining a fully-documented migrant status.

What does this paper add to the wider body of geographical literature on migration and transnationalism? Three things. First, it demonstrates that migration systems are in continuous evolution. Albanian migration is changing fast, and this dynamism implies not only changing space-time patterns (conversion of temporary to long-term migration, new destinations

\footnotetext{
6 These conclusions mainly apply to northern Albania, where most of our remittance material for this paper was collected. However, new research that we are currently doing in southern Albania, financed by the United Nations International Research and Training Institute for the Advancement of Women (UN-INSTRAW), reveals that, here, women are responsible for managing a considerable part of the remittance inflow.
} 
Accepted Manuscript (AM) of King, R. and Vullnetari, J. (2009) The intersections of gender and generation in Albanian migration, remittances and transnational care. Geografiska Annaler: Series B, Human Geography 91(1): 19-38 [DOI: 10.1111/j.14710374.2008.00189.x][accepted 11 August 2008; published March 2009].

etc.), but also changing generational and gender dynamics. Not always, however, do these gender-generational changes result in the freeing of younger women from patriarchal control. Second, some of our findings contribute to plugging significant gaps in the literatures on migration, remittances and transnational care. For instance, our focus on the gendering of remittances opens a line of investigation which surely needs to be followed in other migratory contexts. The same can be said for our research on the multiple roles of older people in the migratory process - both those who experience vulnerability through being 'left behind', and who need care, and those who are anxious to give care and to participate actively in trans-border mobility. Third, the post-communist context suggests both the special nature of the geo-historical setting, and the potential for comparative research in other countries where migration is triggered and then fundamentally shaped by abrupt political and economic transformation. Within Albania, there is a need for more systematic comparison of low-skill and highly-educated migrants (of both sexes), of rural and urban origins, and of differences in migration behaviour and outcomes between northern and southern Albania.

Acknowledgements: As well as the funding bodies which supported the research on which this paper is based (Leverhulme Trust, Oxfam GB and ESRC), we acknowledge the important contribution of Mirela Dalipaj and Nicola Mai, who conducted some of the interviews, and of course the informants whose testimonies enrich the account. We also thank Örjan Sjöberg and five referees for their encouraging remarks and suggestions. A first version of this paper was prepared for the Workshop on Migration, Gender and Generations organised under the aegis of the Development Research Centre on Migration, Globalisation and Poverty, University of Sussex, 19-20 April 2007; we thank the participants, and especially the workshop organiser Ann Whitehead, for their useful comments. 
Accepted Manuscript (AM) of King, R. and Vullnetari, J. (2009) The intersections of gender and generation in Albanian migration, remittances and transnational care. Geografiska Annaler: Series B, Human Geography 91(1): 19-38 [DOI: 10.1111/j.1471-

0374.2008.00189.x][accepted 11 August 2008; published March 2009].

Russell King and Julie Vullnetari

Sussex Centre for Migration Research

University of Sussex

Brighton BN1 9SJ

UK

R.King@sussex.ac.uk

J.Vullnetari@sussex.ac.uk

\section{REFERENCES}

ANTHIAS, F. (2000): 'Metaphors of home: gendering new migrations in Southern Europe', in ANTHIAS, F. and LAZARIDIS, G. (eds) Gender and Migration in Southern Europe. Berg, Oxford, 15-47.

ARREHAG, L., SJÖBERG, Ö. and SJÖBLOM, M. (2005): 'Cross-border migration and remittances in a post-communist society: return flows of money and goods in Korçë district, Albania', South Eastern Europe Journal of Economics 3(1): 9-40.

ARREHAG, L., SJÖBERG, Ö. and SJÖBLOM, M. (2006): 'Post-communist cross-border migration in south-eastern Albania: Who leaves? Who stays behind?', Journal of Ethnic and Migration Studies 32(3): 377402.

BACKER, B. (1983): 'Mother, sister, daughter, wife: the pillars of traditional Albanian patriarchal society', in UTAS, B. (ed.) Women in Islamic Societies: Social Attitudes and Historical Perspectives. Curzon Press, London, 48-65.

BALDASSAR, L. (2007): 'Transnational families and aged care: the mobility of care and the migrancy of ageing', Journal of Ethnic and Migration Studies 33(2): 275-297.

BALDASSAR, L. and BALDOCK, C. (2000): 'Linking migration and family studies: transnational migrants and the care of ageing parents', in AGOZINO, B. (ed.) Theoretical and Methodological Issues in Migration Research: Interdisciplinary, Intergenerational and International Perspectives. Ashgate, Aldershot, 61-89. 
Accepted Manuscript (AM) of King, R. and Vullnetari, J. (2009) The intersections of gender and generation in Albanian migration, remittances and transnational care. Geografiska Annaler: Series B, Human Geography 91(1): 19-38 [DOI: 10.1111/j.1471-

0374.2008.00189.x][accepted 11 August 2008; published March 2009].

BALDOCK, C. (2000): 'Migrants and their parents: care-giving from a distance', Journal of Family Issues 21(2): 205-224.

BARJABA, K. (2000): 'Contemporary patterns in Albanian emigration', South-East Europe Review 3(2): 57-64.

BARJABA, K. and KING, R. (2005): 'Introducing and theorising Albanian migration', in KING, R., MAI, N. and SCHWANDNER-SIEVERS, S. (eds) The New Albanian Migration. Sussex Academic Press, Brighton, $1-28$.

BJERÉN, G. (1997): ' Gender and reproduction', in HAMMAR, T., BROCHMANN, G. TAMAS, K. and FAIST, T. (eds) International Migration, Immobility and Development. Berg, Oxford, 219-246.

BLUE, S.A. (2004): 'State policy, economic crisis, gender, and family ties: determinants of family remittances to Cuba', Economic Geography 80(1): 63-82.

BONIFAZI, C. and SABATINO, D. (2003): 'Albanian migration to Italy: what official data and survey results can reveal', Journal of Ethnic and Migration Studies 29(6): 967-995.

CARVER, R. (1999): The Accursed Mountains: Journeys in Albania, Flamingo, London.

CASTALDO, A. and REILLY, B. (2007): 'Do migrant remittances affect the consumption patterns of Albanian households?', South Eastern Europe Journal of Economics 5(1): 25-54.

DAHINDEN, J. (2008): 'Deconstructing mythological foundations of ethnic identities and ethnic group formation: Albanian-speaking and new Armenian migrants in Switzerland', Journal of Ethnic and Migration Studies 34(1): 55-76.

DALIPAJ, M. (2005): Albanian Migration to the UK: A Hidden Migration? University of Sussex, Brighton, MPhil thesis in Migration Studies.

DE RAPPER, G. (2004): "We are not Greek, but... ': dealing with the GreekAlbanian border among the Albanian-speaking Christians of southern Albania', Southeast European and Black Sea Studies 4(1): 162-174. 
Accepted Manuscript (AM) of King, R. and Vullnetari, J. (2009) The intersections of gender and generation in Albanian migration, remittances and transnational care. Geografiska Annaler: Series B, Human Geography 91(1): 19-38 [DOI: 10.1111/j.1471-

0374.2008.00189.x][accepted 11 August 2008; published March 2009].

DE SOTO, H., GORDON, P., GËDESHI, I. and SINOIMERI, Z. (2002): Poverty in Albania. A Qualitative Assessment. World Bank, Washington DC, Technical Paper 520.

DE ZWAGER, N., GËDESHI, I., GËRMENJI, E. and NIKAS, C. (2005): Competing for Remittances. IOM Tirana, Tirana.

DERVISHI, Z. (2001): Gratë në Syrin e Ciklonit të Sfidave dhe Perspektiva. Trajtesë Sociologjike e Problematikës Sociokulturore të Grave Shqiptare në Vitet' 90 të Shekullit XX, Jerusalem, Tirana.

ESCRIVÁ, A. (2005): Aged global care chains: a Southern-European contribution to the field. Paper presented at the International Conference on Migration and Domestic Work in Global Perspective, Wassenaar, 26-29 May 2005.

FUGA, A. (2004): Shoqëria Periferike: Sociologji e Ndryshimit në Shqipëri, Ora, Tirana.

GEDESHI, I., MARA, H., DHIMITRI, R. and KRISAFI, K. (1999): Emigrimi i elitës intelektuale nga Shqipëria gjatë periudhës së tranzicionit. Luarasi, Tirana.

GOVERNMENT OF ALBANIA (2005): National Strategy on Migration. Government of Albania in cooperation with the International Organisation for Migration, Tirana.

HALPERN, J., KASER, K. and WAGNER, R. (1996): 'Patriarchy in the Balkans: temporal and cross-cultural approaches', The History of the Family 1(4); 425-452.

HATZIPROKOPIOU, P.A. (2003): 'Albanian immigrants in Thessaloniki, Greece: processes of economic and social incorporation', Journal of Ethnic and Migration Studies 29(6): 1033-1057.

HATZIPROKOPIOU, P.A. (2006): Globalisation, Migration and SocioEconomic Change in Contemporary Greece: Processes of Social Incorporation of Balkan Immigrants in Thessaloniki. Amsterdam University Press, Amsterdam.

HONDAGNEU-SOTELO, P. and AVILA, E. (1997): 'I'm here, but I'm there: the meanings of Latina transnational motherhood', Gender and Society 11(5): 548-571. 
Accepted Manuscript (AM) of King, R. and Vullnetari, J. (2009) The intersections of gender and generation in Albanian migration, remittances and transnational care. Geografiska Annaler: Series B, Human Geography 91(1): 19-38 [DOI: 10.1111/j.1471-

0374.2008.00189.x][accepted 11 August 2008; published March 2009].

INSTAT (2002): The Population of Albania in 2001. Main Results of the Population and Housing Census. Instituti i Statistikës, Tirana.

INSTAT (2005): Albania in Figures. Instituti i Statistikës, Tirana.

IOM (2005): World Migration 2005. IOM, Geneva.

KASER, K. (1992): 'The origins of modern Balkan patriarchy', Modern Greek Studies Yearbook 8: 1-39.

KELLY, E. (2005): 'Lifestyles and integration of Albanian women in Bologna. Two steps forward, one step back?', in KING, R., MAI, N. and SCHWANDNER-SIEVERS, S. (eds) The New Albanian Migration. Sussex Academic Press, Brighton, 29-63.

KERA, G. and PAPA, E. (2003): 'Familja, feja dhe e drejta zakonore në Shqipëri deri në gjysmën e parë të shekullit XX', Politika dhe Shoqëria 1(11): 17-30.

KERTZER, D. I. (1983): 'Generation as a sociological problem', Annual Review of Sociology, 9: 129-149.

KING, R. (2005): 'Albania as a laboratory of for the study of migration and development', Journal of Southern Europe and the Balkans 7(2): 133156.

KING, R. and MAI, N. (2002): 'Of myths and mirrors: interpretations of Albanian migration to Italy', Studi Emigrazione 39(145): 161-199.

KING, R. and MAI, N. (2004): 'Albanian migrants in Lecce and Modena: narratives of rejection, survival and integration', Population, Space and Place 10(6): 455-478.

KING, R. and VULLNETARI, J. (2006): 'Orphan pensioners and migrating grandparents: the impact of mass migration on older people in rural Albania', Ageing and Society 26(5): 783-816.

KING, R., DALIPAJ, M. and MAI, N. (2006): 'Gendering migration and remittances: evidence from London and Northern Albania', Population, Space and Place, 12(6): 409-434.

KING, R., IOSIFIDES, T. and MYRIVILI, L. (1998): 'A migrant's story: from Albania to Athens', Journal of Ethnic and Migration Studies 24(1): 159-175. 
Accepted Manuscript (AM) of King, R. and Vullnetari, J. (2009) The intersections of gender and generation in Albanian migration, remittances and transnational care. Geografiska Annaler: Series B, Human Geography 91(1): 19-38 [DOI: 10.1111/j.1471-

0374.2008.00189.x][accepted 11 August 2008; published March 2009].

KING, R., MAI, N. and DALIPAJ, M. (2003): Exploding the Migration Myths. Oxfam and the Fabian Society, London.

KING, R., THOMSON, M., FIELDING, T. and WARNES, T. (2006): 'Time, generations and gender in migration and settlement', in PENNINX, R., BERGER, M. and KRAAL, K. (eds) The Dynamics of International Migration and Settlement in Europe. Amsterdam University Press, Amsterdam, 233-267.

KOFMAN, E. (2004): 'Gendered global migration', International Feminist Journal of Politics 6(4): 643-665.

KOFMAN, E., PHIZACKLEA, A., RAGHURAM, P. and SALES, R. (2000): Gender and International Migration in Europe. Routledge, London.

LABRIANIDIS, L. and HATZIPROKOPIOU, P. (2005): 'The Albanian migration cycle: migrants tend to return to their country of origin after all', in KING, R., MAI, N. and SCHWANDNER-SIEVERS, S. (eds) The New Albanian Migration. Sussex University Press, Brighton, 93-138.

LAZARIDIS, G. (2004): 'Albanian migration to Greece: various forms, degrees and mechanisms of (in)exclusion', in BAGANHA, M. I. and FONSECA, M. L. (eds) New Waves: Migration from Eastern to Southern Europe. Luso-American Foundation, Lisbon, 71-90.

LUBONJA, F. (2001): 'Privacy in a totalitarian regime', Social Research 68(1): 236-253.

MAHLER, S.J. and PESSAR, P. (2001): 'Gendered geographies of power: gender across transnational spaces', Identities 7(4): 441-459.

MAI, N. (2001): 'Transforming traditions: a critical analysis of the trafficking and exploitation of young Albanian girls in Italy', in KING, R. (ed.) The Mediterranean Passage: Migration and New Cultural Encounters in Southern Europe. Liverpool University Press, Liverpool, 258-278.

MAI, N. (2002): Between Losing and Finding Oneself. The Role of Italian Television in the Albanian Migration to Italy. University of Sussex, Brighton, DPhil thesis in Media and Cultural Studies.

MAI, N. (2005): 'The Albanian diaspora-in-the-making: media, migration and social exclusion', Journal of Ethnic and Migration Studies 31(3): 543561. 
Accepted Manuscript (AM) of King, R. and Vullnetari, J. (2009) The intersections of gender and generation in Albanian migration, remittances and transnational care. Geografiska Annaler: Series B, Human Geography 91(1): 19-38 [DOI: 10.1111/j.1471-

0374.2008.00189.x][accepted 11 August 2008; published March 2009].

MARCUS, G.E. (1995): 'Ethnography in the world system: the emergence of multi-sited ethnography', Annual Review of Anthropology 25: 95-117.

McKAY, D. (2005): 'Reading remittance landscapes: female migration and agricultural transition in the Philippines', Geografisk Tidsskrift 105(1): 89-99.

MURZAKU, I.A. and DERVISH, Z. (2003): 'Albanians' first post-communist decade. Values in transition: traditional or liberal?' East European Quarterly 37(2): 231-256.

ORGOCKA, A. (2005): 'Albanian highly skilled women in the US', in KING, R., MAI, N. and SCHWANDNER-SIEVERS, S. (eds) The New Albanian Migration. Sussex Academic Press, Brighton, 139-153.

PESSAR, P. and MAHLER, S. (2003): 'Transnational migration: bringing gender in', International Migration Review, 37(3): 812-846.

PIPER, N. (2005): Gender and Migration. Global Commission on Migration Paper 10, Geneva.

PRATSINAKIS, E. (2005): 'Aspirations and strategies of Albanian immigrants in Thessaloniki', Journal of Southern Europe and the Balkans 7(2): 195-212.

RAMÍREZ, C., GARCIA DOMINGUEZ, M. and MÍGUEZ MORAIS, J. (2005): Crossing Borders: Remittances, Gender and Development. United Nations INSTRAW, Santo Domingo, Working Paper.

RAPPORT, N. (1995): 'Migrant selves and stereotypes: personal context in a postmodern world', in PILE, S. and THRIFT, N. (eds) Mapping the Subject: Geographies of Cultural Transformation, Routledge, London, 267-282.

SCHWANDNER-SIEVERS, S. and FISCHER, B., eds (2002): Albanian Identities: Myth and History. Hurst, London.

SEMYONOV, M. and GORODZEISKY, A. (2005): 'Labor migration remittances and household income: a comparison between Filipino and Filipina overseas workers', International Migration Review 34(1): 4568. 
Accepted Manuscript (AM) of King, R. and Vullnetari, J. (2009) The intersections of gender and generation in Albanian migration, remittances and transnational care. Geografiska Annaler: Series B, Human Geography 91(1): 19-38 [DOI: 10.1111/j.1471-

0374.2008.00189.x][accepted 11 August 2008; published March 2009].

SHRYOCK, A.J. (1988): 'Autonomy, entanglement, and the feud: prestige structures and gender values in Highland Albania', Anthropological Quarterly 61(3): 113-118.

SILVEY, R. (2004): 'Power, difference and mobility: feminist advances in migration studies', Progress in Human Geography 28(4): 490-506.

SILVEY, R. (2006): 'Geographies of gender and migration: spatializing social difference', International Migration Review 40(1): 64-81.

SJÖBERG, Ö. (1991): Rural Change and Development in Albania. Westview, Oxford.

SKELDON, R. (1997): Migration and Development: A Global Perspective. Longman, London.

SOKOLI, L. (2006): Analiza Sociologjike, Instituti i Sociologjisë, Tirana.

SOKOLI, N. and AXHEMI, S. (2000): 'Emigration in the period of transition in Albania', Studi Emigrazione 37(139): 521-529.

TARIFA, F. (2007) 'Of mice, men, and mountains: justice Albanian style', Sociological analysis 1(1): 77-107.

THOMSON, M. and CRUL, M. (2007): 'The second generation in Europe and the United States: how is the transatlantic debate relevant for further research on the European second generation?' Journal of Ethnic and Migration Studies, 33(7): 1025-1041.

TIRTA, M. (1999): 'Migrime të shqiptarëve, të brendshme dhe jashtë atdheut (vitet '40 të shek.XIX-vitet '40 të shek.XX)', Etnografia Shqiptare, 18.

UÇI, A. (2003): 'Mbi disa aspekte të marrëdhënieve familjare dhe martesore', Politika dhe Shoqëria 1(11): 17-30.

UNDP-ALBANIA (2005): National and Human Development Report Albania 2005: Pro-Poor and Pro-Women Policies and Development in Albania. UNDP, Tirana.

VULLNETARI, J. and KING, R. (2008): 'Does your granny eat grass? On mass migration, care drain and the fate of older people in rural Albania', Global Networks 8(2): 139-161.

WEINER, M. (1995): The Global Migration Crisis. Harper Collins, New York. 
Accepted Manuscript (AM) of King, R. and Vullnetari, J. (2009) The intersections of gender and generation in Albanian migration, remittances and transnational care. Geografiska Annaler: Series B, Human Geography 91(1): 19-38 [DOI: 10.1111/j.1471-

0374.2008.00189.x][accepted 11 August 2008; published March 2009].

WHITAKER, I. (1981): 'A sack for carrying things: the traditional role of women in Northern Albanian society', Anthropological Quarterly 54(2): 146-156.

WILLIS, K. and YEOH, B. eds. (2000): Gender and Migration. Berg, Oxford.

WONG, M. (2006): 'The gendered politics of remittances in Ghanaian transnational families', Economic Geography 82(4): 355-381.

WORLD BANK (2006): Albania: Trends in Poverty and Inequality, 20022005. World Bank and Instituti i Statistikës, Tirana.

ZEZZA, A., CARLETTO, G. and DAVIS, B. (2005): 'Moving away from poverty: spatial analysis of poverty and migration in Albania', Journal of Southern Europe and the Balkans 7(2): 175-193.

ZINN, D. and RIVERA, A. (1995): 'Notes on a displaced womanhood: Albanian refugee women in Southern Italy', Anthropology of East Europe Review 13(1): 23-29.

ZONTINI, E. (2001): 'Family formation in gendered migration: Moroccan and Filipino women in Bologna', in KING, R. (ed.) The Mediterranean Passage: Migration and New Cultural Encounters in Southern Europe. Liverpool University Press, Liverpool, 231-257.

ZONTINI, E. (2004): 'Immigrant women in Barcelona: coping with the consequences of transnational lives', Journal of Ethnic and Migration Studies 30(6): 113-144. 